\title{
Communication of Stabilizing Energy between Substructures of a Protein
}

\author{
Richard Kristinsson and Bruce E. Bowler*
}

Department of Chemistry and Biochemistry, 2190 E. Iliff Avenue, University of Denver, Denver,

Colorado 80208-2436, USA

\section{Supporting Information}

\section{GdnHCl denaturation at $695 \mathrm{~nm}$ versus $\theta_{220}$.}
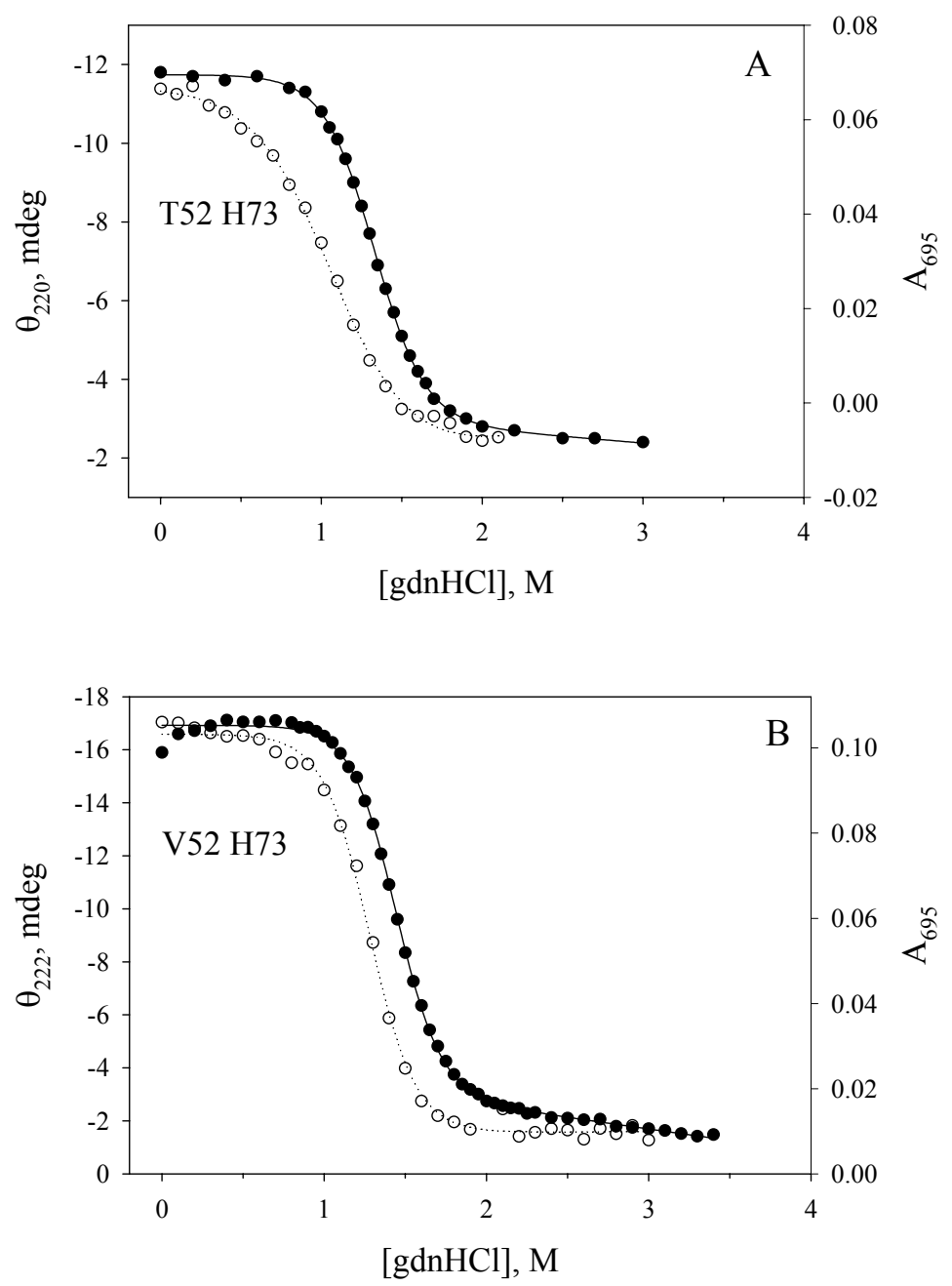


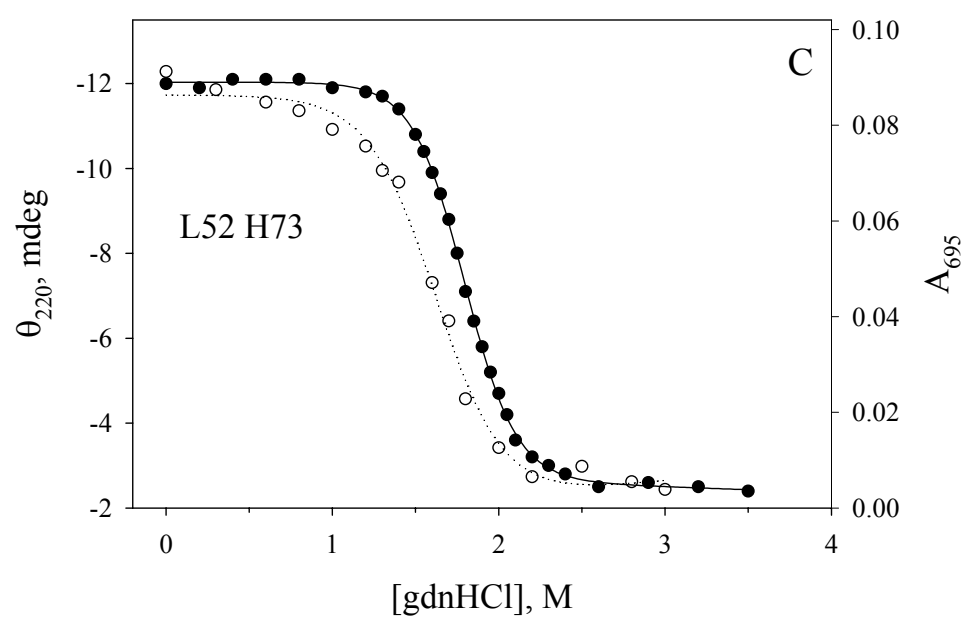

Figure S1. Plots of absorbance at $695 \mathrm{~nm}(\mathrm{O})$ versus gdnHCl concentration and of ellipticity at $220 \mathrm{~nm}$ (or $222 \mathrm{~nm}$ ) versus gdnHCl concentration (•) for A) T52 H73, B) V52 H73 and C) L52 $\mathrm{H} 73$ iso-1-cytochromes $c$. Data were collected in $20 \mathrm{mM}$ Tris, $40 \mathrm{mM} \mathrm{NaCl}$ at $\mathrm{pH}$ 7.5, $25 \pm 0.1$ ${ }^{\circ} \mathrm{C}$ and protein concentrations of $180-190 \mu \mathrm{M}$ at $695 \mathrm{~nm}, 2 \mu \mathrm{M}$ for ellipticity at $220 \mathrm{~nm}$ and 4 $\mu \mathrm{M}$ for ellitpicity at $222 \mathrm{~nm}$. Titrations were carried out as described in Materials and Methods. The solid $\left(\theta_{220}\right.$ or $\left.\theta_{222}\right)$ and dotted $\left(\mathrm{A}_{695}\right)$ curves are nonlinear least squares fits of the data to equations 1 and 3, respectively, in Materials and Methods. 


\section{Alkaline transition versus gdnHCl concentration}
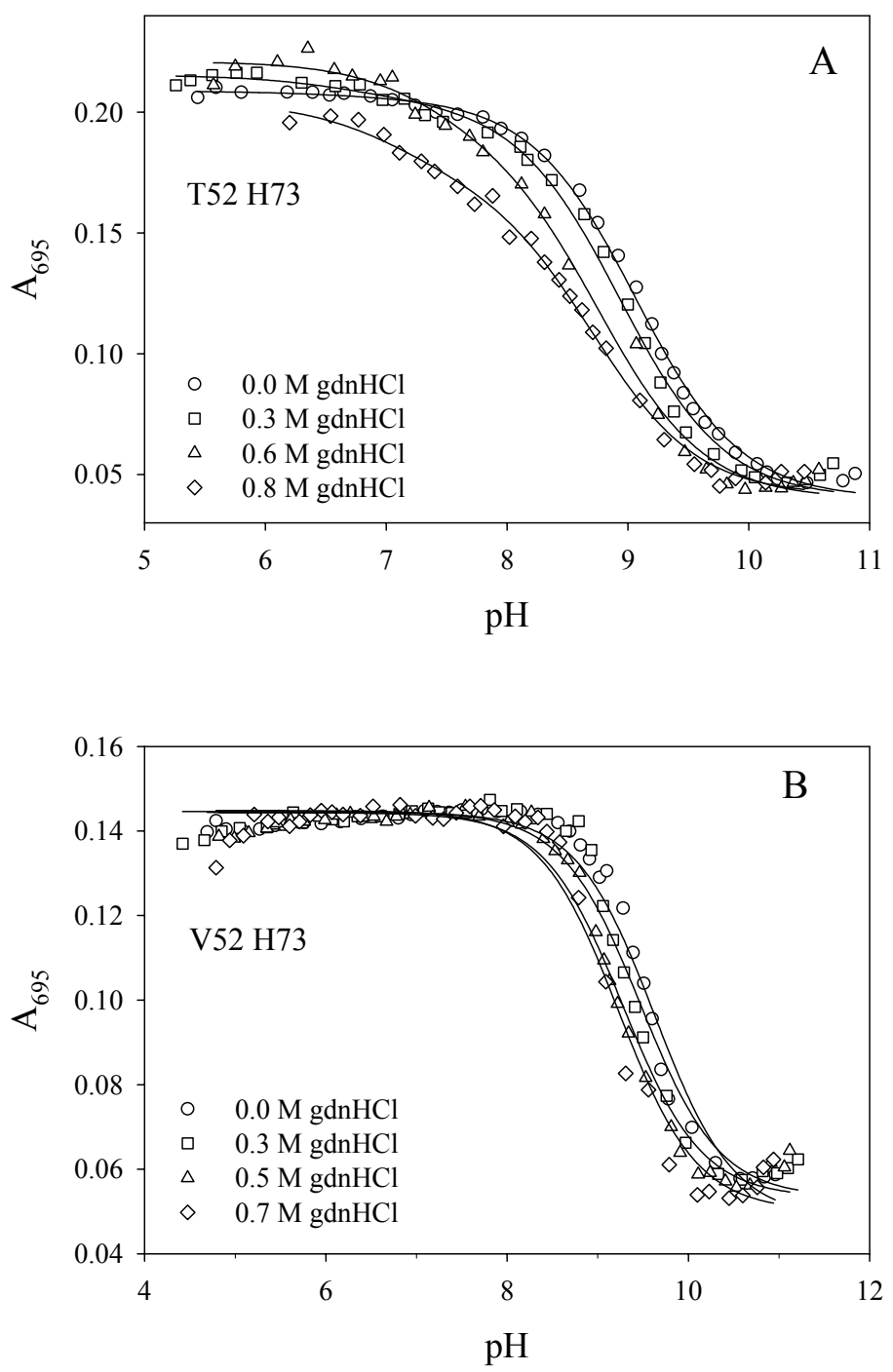

Figure S2. Plots of absorbance at $695 \mathrm{~nm}$ versus pH for A) T52 H73 and B) V52 H73 iso-1cytochromes $c$ at different concentrations of guanidine hydrochloride. Data were collected in 0.1 $\mathrm{M} \mathrm{NaCl}$ at $25 \pm 0.1^{\circ} \mathrm{C}$ at protein concentrations of $190-200 \mu \mathrm{M}$. Titrations were carried out as described in Materials and Methods. The solid curves for the T52 H73 data are fits to equation 4 in Materials and Methods, where $\mathrm{pK}_{\mathrm{H}}\left(\mathrm{T}_{2} \mathrm{H}^{+}\right)=10.8$, the value obtained from kinetic experiments 
for the K79 alkaline state. The solid curves for the V52 H73 data are fits to equation 5 in Materials and Methods, where $\mathrm{pK}_{\mathrm{H}}\left(\mathrm{T}_{2} \mathrm{H}^{+}\right)=10.8$. 